\title{
Concrete crack repair analysis with metakaolin-based geopolymer cement
}

\section{Análise de reparo de fissuras em concreto com cimento geopolimérico a base de metacaulim}
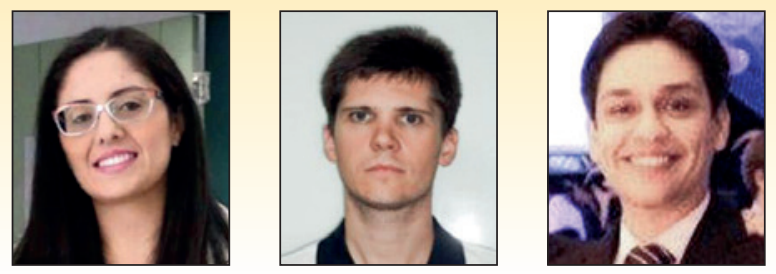

\author{
B. J. FRASSON \\ brunajfrasson@hotmail.com \\ https://orcid.org/0000-0002-1074-0518 \\ F. PELISSER a \\ pelisser@hotmail.com \\ https://orcid org/0000-0002-6113-5473 \\ B. V. SILVA \\ dovalesilva@hotmail.com \\ https://orcid.org/0000-0001-5363-5657
}

\begin{abstract}
Among the advances in the use of geopolymer cements is their use as repair materials in concrete structures. The objective of this work was to use a geopolymer cement to repair cracks in concrete specimens, observing its mechanical performance and fracture modes. Cubic test specimens were produced and two types of cracks were evaluated as variables. Cracks were induced by steel sheets during concreting. The geopolymer cement paste and an epoxy adhesive, as reference, were used for the repairs. The results showed a $13 \%$ decrease in compressive strength for unrepaired concrete, and $3.7 \%$ in concrete repaired with geopolymer. The binder presented mechanical performance similar to that of the epoxy resin regarding crack recovery. In conclusion, repairs made with geopolymer cement are a viable and efficient means of crack recovery.
\end{abstract}

Keywords: geopolymer cement, repair, cracks, epoxy, concrete.

\section{Resumo}

Entre os avanços para o uso de cimentos geopoliméricos encontra-se seu uso como material de reparo em estruturas de concreto. O objetivo desse trabalho foi utilizar uma pasta de cimento geopolimérico no reparo de fissuras em corpos de prova de concreto, observando seu desempenho mecânico e os modos de fraturas. Foram produzidos corpos de prova cúbicos, e, como variáveis, foram avaliados os tipos de fissuras. As fissuras foram induzidas por meio de chapas de aço durante a concretagem. Foram utilizados pasta de cimento geopolimérico e um adesivo epóxi - como referência de desempenho, para os reparos. Os resultados mostraram queda da resistência de $13 \%$ para o concreto sem reparo, e de $3,7 \%$ no reparado com geopolímero. O aglomerante geopolimérico apresentou desempenho mecânico semelhante ao da resina epóxi, para recuperação da fissura. Conclui-se que o reparo com cimento geopolimérico pode ser considerado eficiente para recuperação de fissuras.

Palavras-chave: cimento geopolimérico, reparos, fissuras, epóxi, concreto. 


\section{Introduction}

Cracks are common pathological manifestations in concrete structures, which have several causes and modify the aesthetics, while also compromising the mechanical properties and durability of the construction. Knowledge of the causes and origins is essential to determine the choice of materials and repair methodology and ensure long term durability. The main causes of cracks include volumetric variations, thermal stresses, deleterious chemical reactions, reinforcement corrosion and bad construction practices [1].

Gravity-fill is a crack repair method that uses low viscosity resins (0.03 to $2.00 \mathrm{~mm}$ thick), such as epoxy or high molecular weight methacrylate [2]. When used as crack repair material, epoxy enables the rehabilitation of the concrete mechanical properties [3$4]$, a reduction in chloride ion percolation, evaluated by numerical methods [5]; however, failures can occur at the interface between the concrete and epoxy when subjected to fatigue stress [6].

Geopolymeric cements are obtained by the chemical reaction between alkali metal and silicate powders, the reaction products are three-dimensional amorphous aluminosilicate networks. Their characteristics include high durability [7], low shrinkage [8], good acid resistance [8], good fire resistance [7], low thermal conductivity [9-10] and high temperature resistance [9]. Much of the research on these binders focuses on mechanical properties. Pelisser et al. [11] compared the mechanical behavior of two beams, one with geopolymer concrete and the other with Portland, with the same strength class (C50). The authors observed superior geopolymer steel-concrete adhesion results, showing the potential in developing this type of concrete.

Recent work has shown the efficiency of using geopolymer cements as repair materials for concrete structures. Ding, Cheng and Dai [12] used activated alkali cement pastes to fill inclined cracks in concrete structures. The paste was composed of fly ash and blast furnace slag and, after the repair, the authors analyzed that the rupture occurred in the concrete substrate, indicating that the paste has higher strength. Ueng et al [13] analyzed the adhesion between mortar substrates and activated alkali cements produced with metakaolin, and concluded that by understanding the mechanical models, it is possible to predict the form of rupture and the various stresses that arise in the concrete when geopolymer is used as a structural repair material.

This study aimed to evaluate the use of metakaolin-based geopolymer cement as crack filler in concrete substrates, evaluating its mechanical performance by the compressive strength test. A qualitative analysis of the specimen rupture and finite element simulation was proposed to verify the behavior of the materials used and their interfaces.

\section{Materials and experimental program}

The experiment was designed to verify the mechanical performance of a geopolymer cement paste in the repair of cracks in comparison with a commercially available epoxy resin. Cubic specimens were molded as specified by the standard [14] with the edges of $15 \mathrm{~cm}$. The variables analyzed were the types of cracks in the specimens (longitudinal cracks on opposite faces (LC) and on the same face (TC)) and the form of crack recovery (geopolymer or epoxy resin). The nomenclature adopted for each variable is indicated in Table 1.

Cracks were induced in the specimens (Figure 1) using $2 \mathrm{~mm}$ thick steel plates measuring $35 \mathrm{~mm} \times 150$ and $50 \mathrm{~mm} \times 70 \mathrm{~mm}$ (width $\times$ height), respectively called LC and TC. In LC, the plates were placed in the center of the parallel faces and in TC the plates are fixed in the middle third of the same face. The methodology was based on the work developed by Issa and Debs [4], in which the authors induced cracks in specimens using steel plates.

\subsection{Materials}

The geopolymer cement paste used to repair cracks (LCG and TCG) consisted of metakaolin $\left(45.2 \% \mathrm{Al}_{2} \mathrm{O}_{3}, 53.4 \% \mathrm{SiO}_{2}\right.$ and $0.4 \%$ $\mathrm{PF}$ ) from kaolin calcination at $800^{\circ} \mathrm{C}$ and a solution activator, produced by dissolving $\mathrm{NaOH}$ (Sigma Aldrich - $97 \% \mathrm{Na}_{2} \mathrm{O}$ ) in sodium silicate (Sigma Aldrich - $\mathrm{Na}_{2} \mathrm{OSiO}_{2} \cdot \mathrm{H}_{2} \mathrm{O}$ ) with $63 \%$ water. The molar ratios of the composition were 1.6 for $\mathrm{Na}_{2} \mathrm{OSiO}_{2} / \mathrm{NaOH}, 6.94$ for $\mathrm{SiO}_{2} / \mathrm{Na}_{2} \mathrm{O}, 3.2$ for $\mathrm{SiO}_{2} / \mathrm{Al}_{2} \mathrm{O}_{3}$, and 0.75 for $\mathrm{H}_{2} \mathrm{O} / \mathrm{MK}$. The materials and molar relations used for the production of geopolymer cement were determined in a previous work [15].

The geopolymer cement was mixed by dissolving the $\mathrm{NaOH}$ in sodium silicate, then, with the aid of a mortar, all the liquid was deposited in the vat and the metakaolin was added at low speed. Later, the material was homogenized for $5 \mathrm{~min}$ at high speed.

For crack repair (LCE and TCE), was used an epoxy adhesive, two-component structural adhesive that is recommended for sealing cracks, a product with high adhesion, low viscosity, and high chemical and mechanical resistance.

The concrete produced has a unit composition of 1: 2.58: 2.92 (cement: fine aggregate: coarse aggregate), and $\mathrm{w} / \mathrm{b}$ ratio of 0.45 with $55 \%$ mortar content. CP IV cement, coarse aggregate and

Table 1

Variables used in the study

\begin{tabular}{ccc}
\hline Cracks type & Recovery material & Description \\
\hline No crack & - & L \\
\hline $\begin{array}{c}\text { Longitudinal cracks in parallel faces } \\
(35 \mathrm{~mm} \times 150 \mathrm{~mm})\end{array}$ & Without-recovering & LCE \\
\hline $\begin{array}{c}\text { Cracks in the middle third of the same } \\
\text { face }(50 \mathrm{~mm} \times 70 \mathrm{~mm})\end{array}$ & Epoxy & Geopolymer \\
& Without-recovering & TC \\
\hline
\end{tabular}



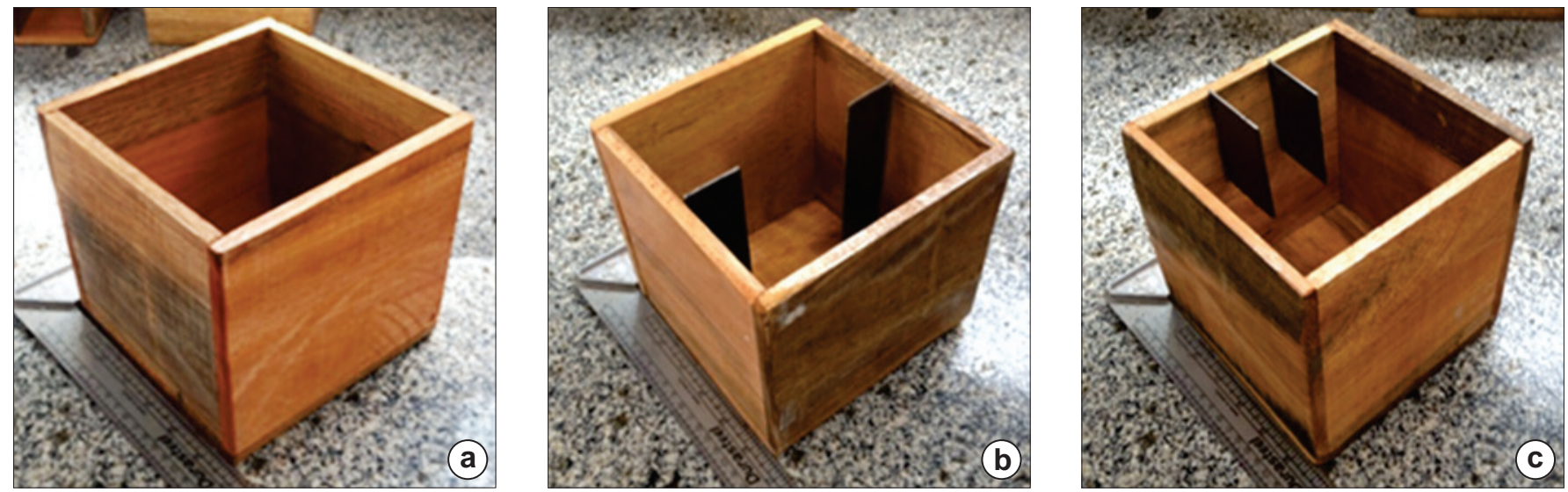

\section{Figure 1}

Schematic representation of samples and induced cracks (a) control group (M); (b) longitudinal cracks (LC); (c) cracks in the middle third of the face (TC)

medium sand with a fineness modulus of 2.5 , determined according to ABNT NBR 7211 [16] were used.

\subsection{Methods}

After the concrete was mixed, the specimens were molded, air cured for $24 \mathrm{~h}$, demolded and subjected to immersion curing up to 21 days. At this age, the repair materials (geopolymer and epoxy) were applied. The repair consisted of a process of drying, cleaning, and filling the cracks by gravity, until the materials overflowed and the excess was removed.

Twenty-four hours after the repair application, the specimens were submitted to submerged cure until the concretes were 28 days of age, when the compressive strength test was performed. Figure 2 shows the specimens after filling the cracks. Prior to rupture, the specimens were capped using a w/b ratio of 0.4 . The compression test followed NP EN 12390-3 [17]. Figure 3 shows the direction of load application on the specimens. The experimental results were submitted to analysis of variance (ANOVA), with $95 \%$ reliability. Under the same loading conditions and pre-established cracks, simulations were performed by the finite element method (FEM), with the aid of the ANSYS tool, to evaluate and validate the results. The elements had eight nodes (SOLID65), used for 3D modeling of solids, which can be crushed during compression, and each node has three degrees of freedom. Validation of the simulation results was obtained by statistical hypothesis tests, adopting a coefficient of variation of $10 \%$ in relation to the average experimental compressive strength $(\mathrm{M})$ in the control group.

The properties of the materials used for the FEM model are described in Table 2, the geopolymer data were obtained from a pre-
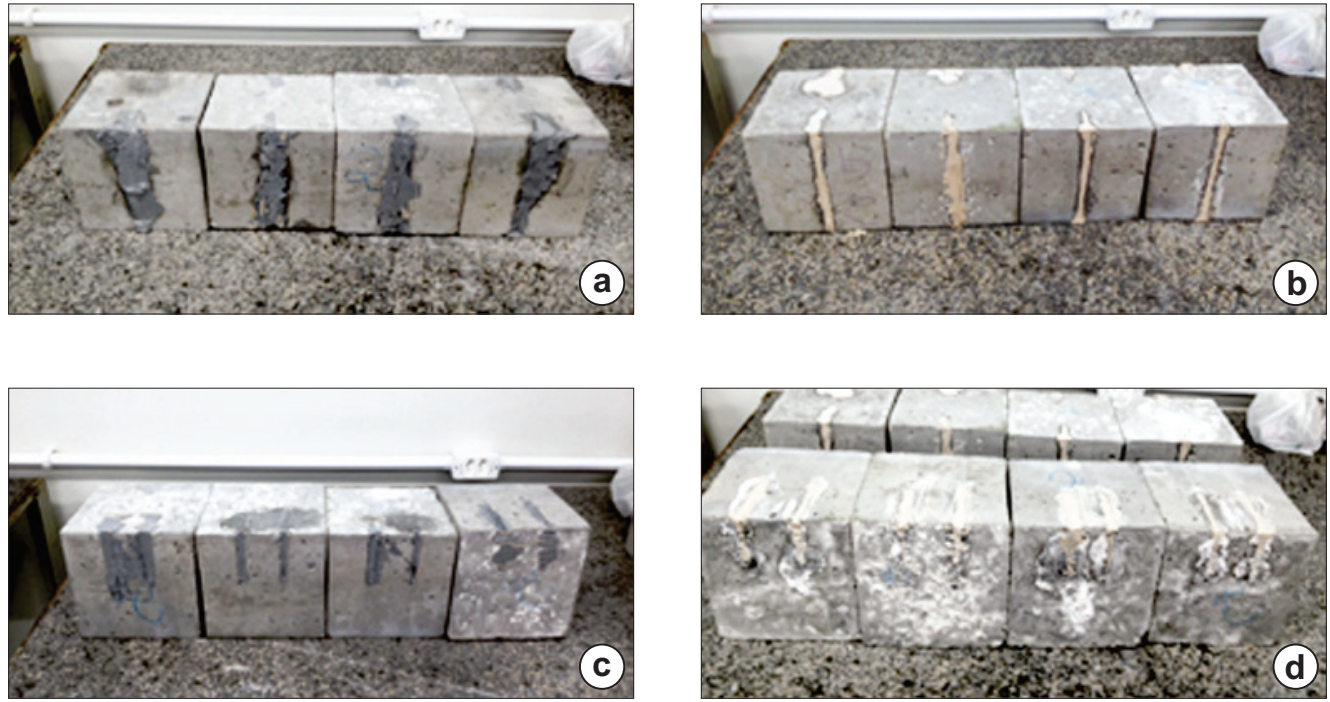

\section{Figure 2}

Recovery specimens (a) LC-Epoxy; (b) LC-Geopolymer; (c) LC-Epoxy; (d) LC-Geopolymer 

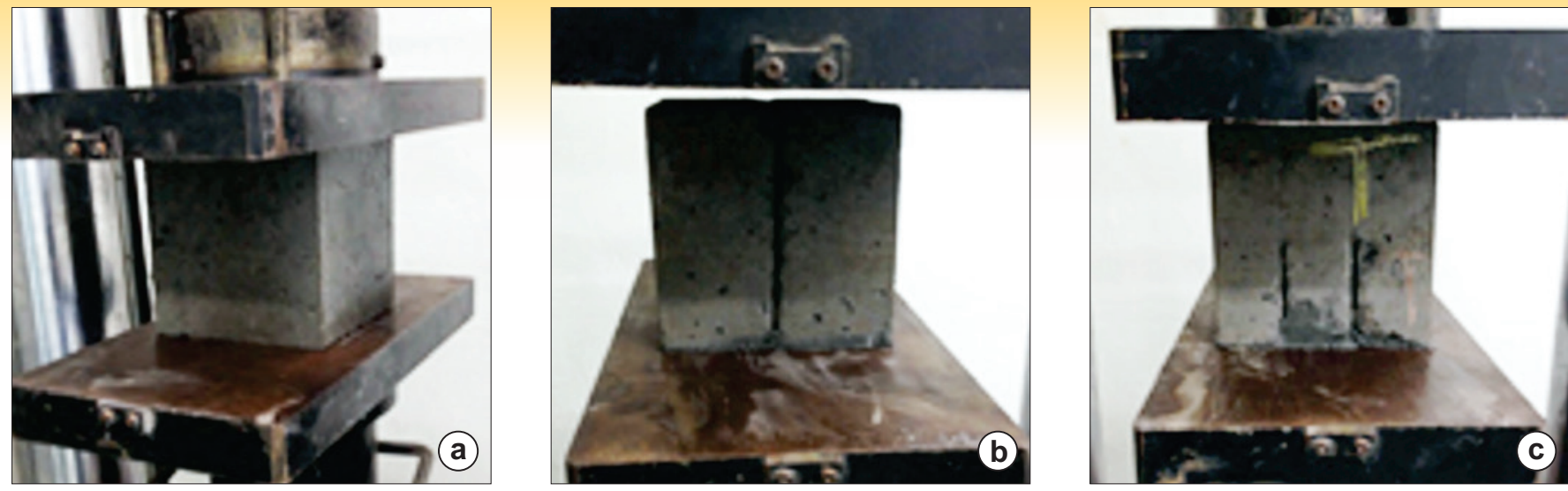

\section{Figure 3}

Direction of application of loads on specimens

\section{Table 2}

Mechanical and physical properties used in finite elements analysis

\begin{tabular}{cccc}
\hline Characteristics & Epoxi & Geopolymer & OPC Concrete \\
\hline Elastic modulus (GPa) & 10.6 & 10.0 & 29.0 \\
Compressive strength (MPa) & 69.0 & 64.0 & 35.0 \\
Density $\left(\mathrm{g} / \mathrm{cm}^{3}\right)$ & 1.80 & 1.50 & 2.30 \\
\hline
\end{tabular}

vious work [15], the epoxy properties were taken from the ANSYS database and the manufacturer [18], and for the concrete, a characteristic compressive strength of $35 \mathrm{MPa}$ was established, with an estimated modulus of elasticity of $29 \mathrm{GPa}$, as shown by NBR 6118 [19]. Poisson's ratio was 0.2 for all materials.

\section{Results and discussions}

\subsection{Compressive strength}

The results of the compressive strength test are presented in Figure 4. The experimental control group obtained an average compressive strength of $37 \mathrm{MPa}$, and the groups with no filling presented a reduction in compressive strength of approximately $12 \%$ and $13 \%$ compared with this group (M). Statistical analysis of the specimens following crack repairs by geopolymer cement and epoxy showed that these materials were efficient at recovering the mechanical strength of the specimens. There were no significant differences between the different types of configuration and recovery materials (Table 3 ).

The mean loads were 821 kN, 734 kN, 724 kN, 812 kN, 872 kN, $854 \mathrm{kN}$ and $826 \mathrm{kN}$, respectively, for M, LC, TC, LCE, LCG, TCE and TCG. These loads were adopted for use in the MEF simulation of the specimens. Table 4 presents the results obtained

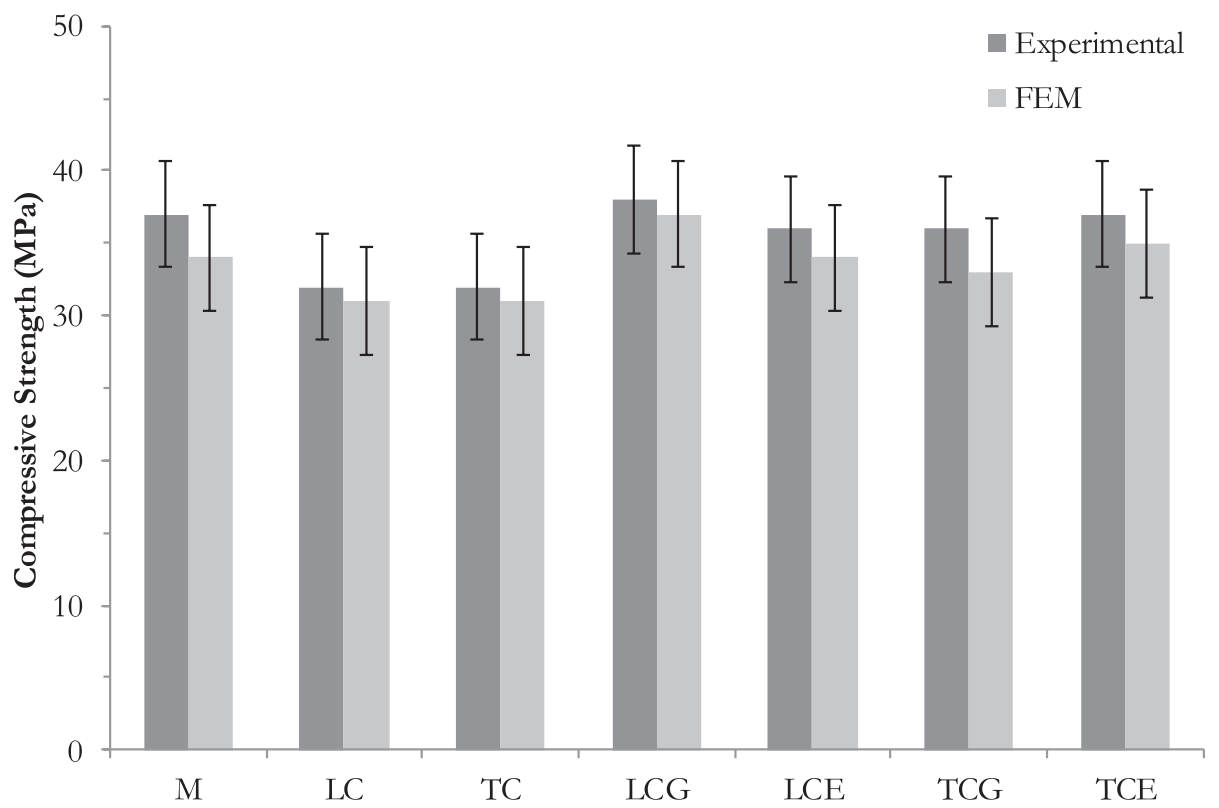

Figure 4

Compressive strength results at 28 days 
Table 3

ANOVA results $(\alpha=0.05)$

\begin{tabular}{cccccc}
\hline Source & Degree of freedom & Sum squares & Mean squares & $\mathbf{F}$ & $\mathbf{P}_{\mathbf{r}}>\mathbf{F}_{\mathrm{c}}$ \\
\hline Source & 6 & 22.15 & 132.91 & 2.1793 & 0.08634 \\
Error & 21 & 10.16 & 213.46 & - & - \\
\hline
\end{tabular}

\section{Table 4}

Compressive strength of experimental and simulated results (MPa)

\begin{tabular}{ccccccccc}
\hline Procedure & $\mathbf{M}$ & LC & TC & LCG & LCE & TCG & TCE & CS \\
\hline Experimental & 37 & 32 & 32 & 38 & 36 & 36 & 37 & $34 \mathrm{MPa}$ \\
Simulated & $(4.4)$ & $(2.2)$ & $(3.3)$ & $(1.8)$ & $(3.3)$ & $(2.8)$ & $(3.7)$ & $(3.69)$ \\
\hline
\end{tabular}

experimentally and by simulation. Adopting the statistical hypothesis test and using the experimental mean of the control group (M), a minimum compressive strength of $34 \mathrm{MPa}$ was obtained, such that values lower than this were rejected by the test.

The M-Simulated, LCG-Simulated, LCE-Simulated and TCESimulated groups were statistically similar to the experimental group $\mathrm{M}$, with resistance close to and above $34 \mathrm{MPa}$, and variations of up to $9 \%$. However, the TCG-Simulated group presented compressive strength close to that established by the hypothesis, with a reduction of $2 \%$. The other groups presented negative variations close to $10 \%$, that is, they showed a larger decrease in compressive strength compared with the experimental data.

Filling cracks using geopolymer paste and epoxy presented experimental data similar to solid concrete, so the mechanical properties of the specimens were restored. FEM simulation analysis was validated by the statistical hypothesis test because the compressive strength values of the repaired materials were similar to the experimental control group.

\subsection{Analysis of specimen rupture}

After the compressive strength test, images were recorded to analyze the rupture modes, considering the appearance of cracks, concrete detachment and material resistance.

In the concrete group (M) specimens, the center remained intact, while detachment of the extremities occurred, together with the appearance of cracks at approximately $45^{\circ}$ (Figure 5).
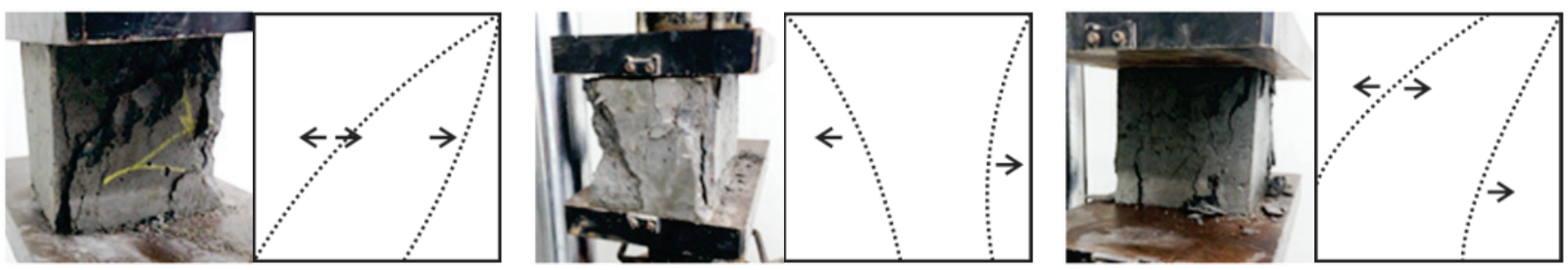

\section{Figure 5}

Crack propagation during the compressive strength test in group $M$
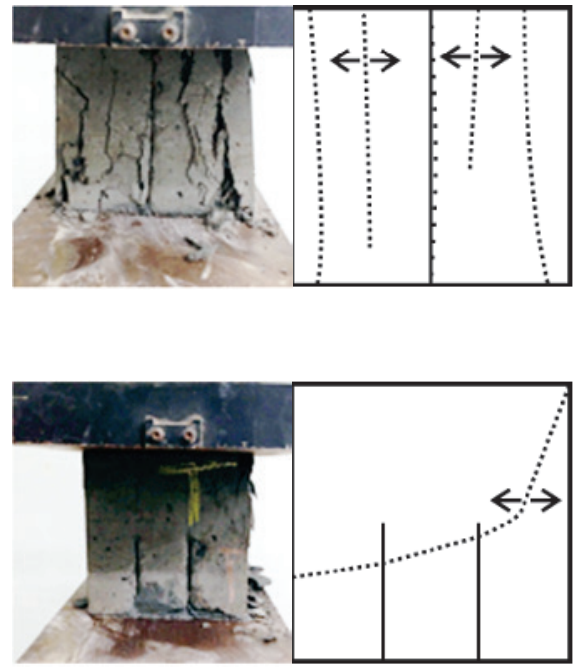

Figure 6

Crack propagation during the compressive strength test on induced crack specimens, (a) LC; (b) TC

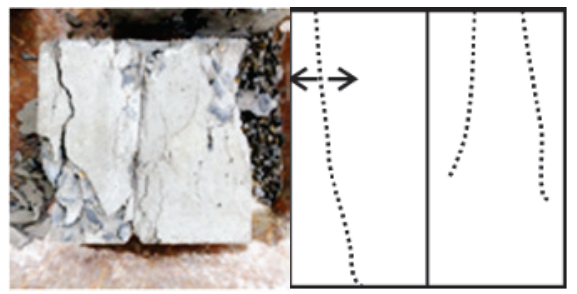

(a)

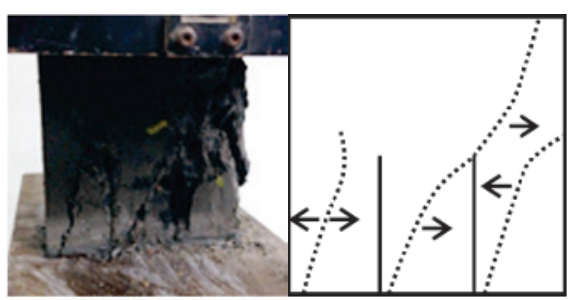

(b)
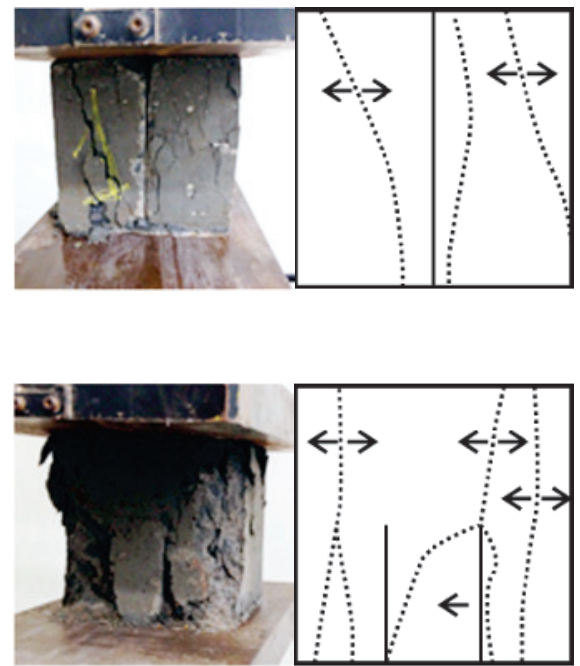

b) 
In the LC and TC samples, the induced fissure showed crushing, indicating rupture of the specimen, and load application caused the appearance of normal cracks in the LC and perpendicular cracks in the TC (Figure 6), similar to those reported by Issa and Debs [4].

In the groups in which the cracks were filled, substrate rupture was observed instead of the filler materials. There was no detachment of substrate filling materials, indicating good adhesion between these materials. Very similar behavior was observed by Ding et al. [12].

LCE and LCG samples (Figure 7) showed cracks parallel to those induced. In the TCE and TCG specimens (Figure 8), the cracks initially formed an angle of approximately $45^{\circ}$, but when these met the induced crack and crossed it, the cracks changed direction.

Figure 9 shows the images taken from ANSYS after the simu- lations were performed. The highest stress intensity was observed in the concrete matrix, rather than the repair materials, suggesting that the specimen rupture occurs in the matrix due to its lower strength in relation to the filler material. This analysis is related to the experimental results, since the ruptures actually occurred in the concrete substrate.

The good adhesion between the concrete substrate and the repair material could be related to the methodology used to prepare the crack surfaces and their subsequent filling. Following the correct cleaning and filling procedures allowed the materials to exhibit good mechanical behavior when bonded.

The fracture mode analysis was positive regarding the behavior of the materials used, but complementary tests, such as adhesion, tensile strength and durability, are necessary to verify the performance of the repairs made.
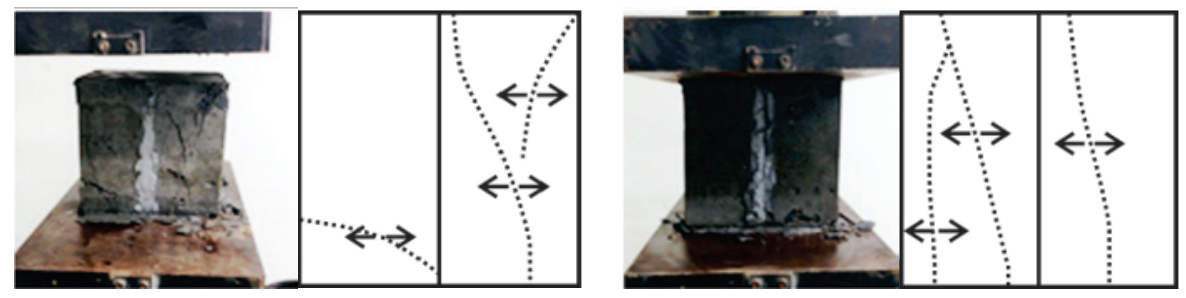

(a)
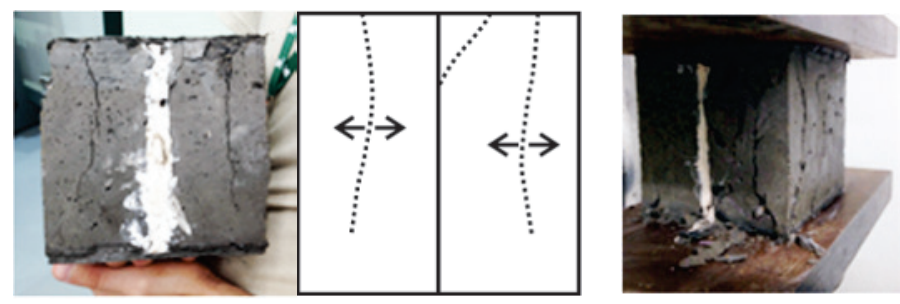

(b)
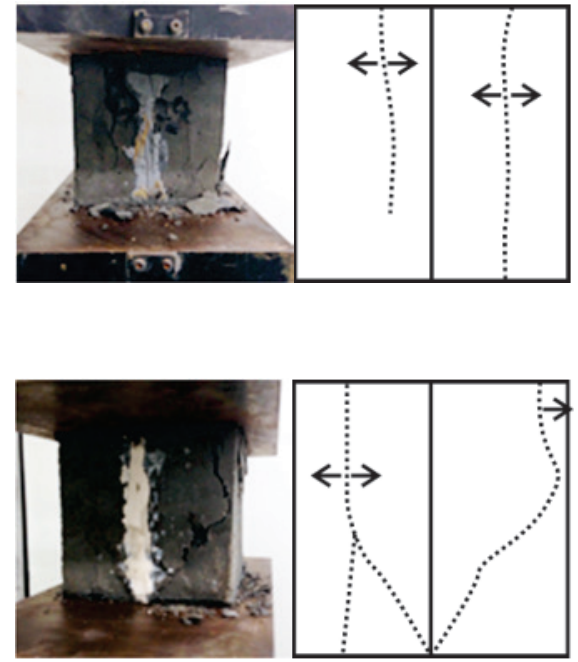

\section{Figure 7}

Crack propagation during the compressive strength test on specimens with recovered induced cracks (a) LCE; (b) LCG
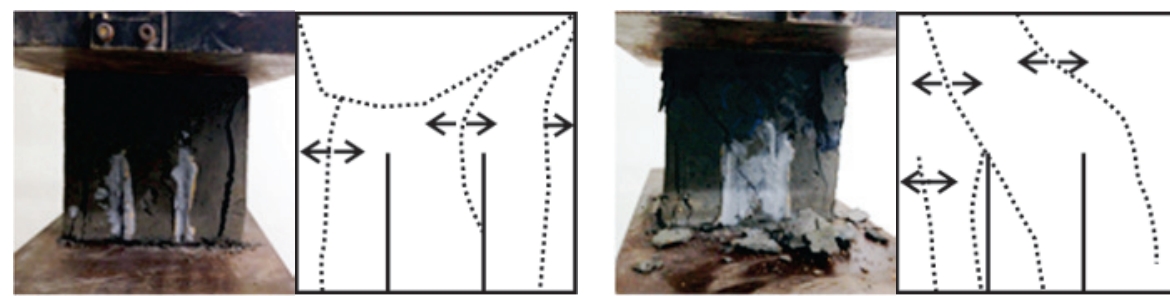

(a)
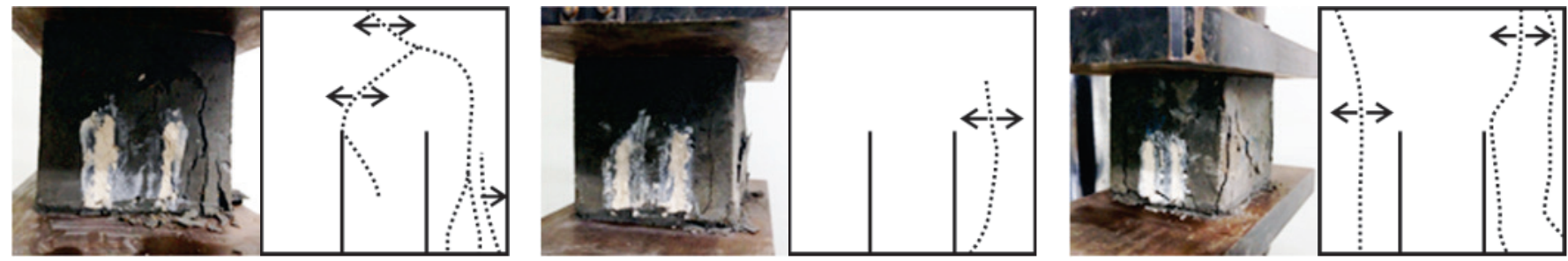

(b)

\section{Figure 8}

Crack propagation during the compressive strength test on specimens with recovered induced cracks (a) TCE; (b) TCG 


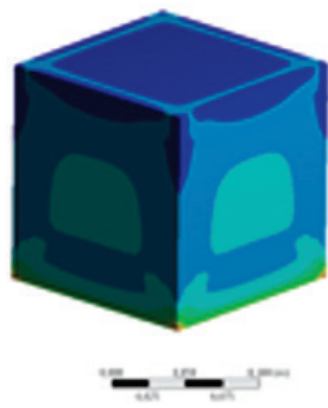

(a)

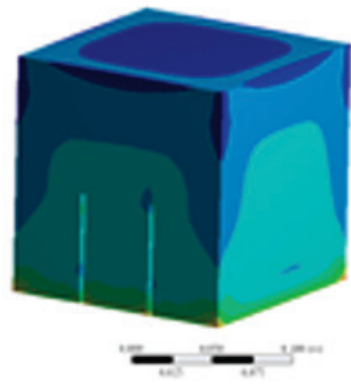

(b)

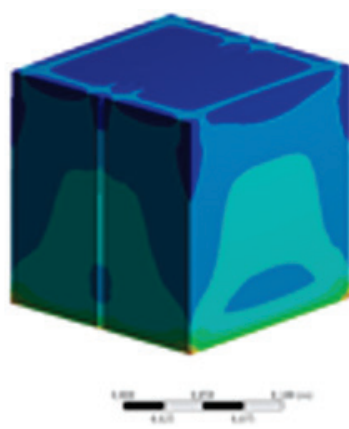

(c)

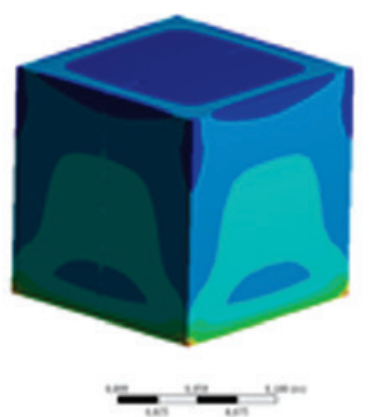

(d)

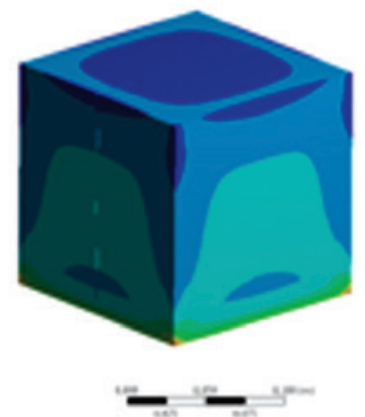

(e)

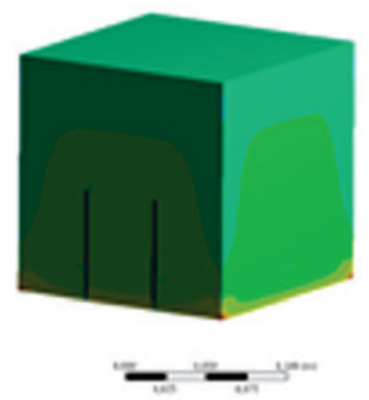

(

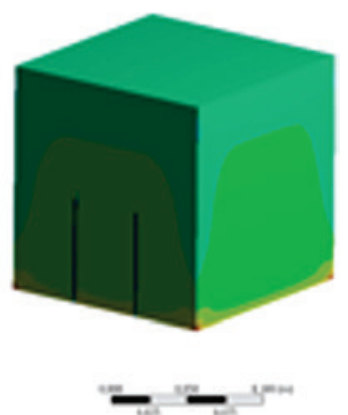

(9)

Figure 9

FEM simulation images of specimens (a) M; (b) LC; (c) TC; (d) LCE; (e) LCG; (f) TCE; (g) TCG

\section{Conclusions}

This research analyzed the mechanical performance of geopolymer cement as a material for crack recovery compared with the common practice of applying epoxy. The results show that it is possible to use geopolymer cement as a filler material for cracks in experimental compressive strength concrete structures in specimens with opposite face (LCG) and single face (TCG) cracks of $38 \mathrm{MPa}$ and $36 \mathrm{MPa}$, respectively. These values are greater than or equivalent to the strength of the reference concrete. Fractures occurred in the concrete substrates, due to the good adhesion at the interface between the materials, and the superior mechanical resistance of the fillers in relation to the substrate. Filling the induced cracks with the repair cements transformed the specimen into a monolithic material.

The finite element analysis presented similar results to the experimental data, and the model adopted was shown to be relevant for the simulation of the compressive strength of cracked concrete, whether restored (crack filling) or not. These results show a new potential for the application of geopolymer cements, considering their satisfactory cohesion properties and adhesion, and they are competitive with the recovery materials available on the market.

\section{Acknowledgements}

The authors are grateful for the financial support from the National Council for Scientific and Technological Development (CNPq).

\section{References}

[1] American Concrete Institute - ACl Committee 224. Causes, evalution, and repair of cracks in concrete structures (224.1R-93). Farmington Hills (MI): American Concrete Institute, 1993. 22 p.

[2] American Concrete Institute - ACl Committee E706. Crack repair by gravity feed with resin (ACI RAP Bulletin 2). Farmington Hills (MI). American Concrete, 2003. 4 p.

[3] Ahmad S; Elahi A., Barbhuiya S, Farooqi Y. Repair of cracks in simply supported beams using epoxy injection technique. Materials And Structures, v. 46, n. 9, 2013, p. 1547-1559.

[4] Issa CA; Debs P. Experimental study of epoxy repairing of cracks in concrete. Construction and Building Materials, v. 21 , n. 1, 2007, p. 157-163.

[5] Jones SZ, Bentz DP, Davis JM, Hussey DS, Jacobson DL, Molloy JL, Sieber JR. Measurement and modeling of the ability of crack fillers to prevent chloride ingress into mortar. Cement and Concrete Composites, v. 81, 2017, p. 109-121.

[6] Hin H, Miyauchi H; Tanaka K. An experimental study of fatigue resistance in epoxy injection for cracked mortar and concrete considering the temperature effect. Construction and Building Materials, v. 25, n. 3, 2011, p. 1316-1324.

Komnitsas K, Zaharaki D. Geopolymerisation: a review and prospects for the minerals industry. Minerals Engineering, n. 20, 2007, p. 1261-1277. 
[8] Duxson P. Geopolymer technology: the current state of the art. Journal of Materials Science, n. 42, 2007, p. 2917-2933.

[9] Villaquirán-Caicedo MA, Gutiérrez RM, Sulekar S, Davis C, Nino JC. Thermal properties of novel binary geopolymers based on metakaolin and alternative silica sources. Applied Clay Science, v. 118, 2015, p.276-282.

[10] Robati M; Kokogiannakis G, MCCarthy TJ. Impact of structural design solutions on the energy and thermal performance of an Australian office building. Building and Environment, v. 124, 2017, p.258-282.

[11] Pelisser, F., Silva, B. V., Menger, M. H., Frasson, B. J., Keller, T. A., Torii, A. J., Lopez, R. H. Structural analysis of composite metakaolin-based geopolymer concrete. Revista IBRACON de Estruturas e Materiais, v. 11, n. 3 , 2018, 535-543.

[12] Ding YC, Cheng TW, Dai YS. Application of geopolymer paste for concrete repair. Structural Concrete, v. 18, n. 4, 2017, p. 561-570.

[13] Ueng TH, Lyu SJ, Chu HW, Lee HH, Wang TT. Adhesion at interface of geopolymer and cement mortar under compression: An experimental study. Construction and Building Materials, v. 35, 2012, p. 204-210.

[14] BRITISH STANDARD. Testing hardened concrete: shape, dimensions and other requirements for specimens and molds: NP EN 12390-1. 2003.

[15] Pelisser F, Guerrino E.L, Menger M, Michel M.D, Labrincha JA. Micromechanical caracterization of metakaolinbased geopolymers. Construction and Building Materials, v. 49,2013 , p. $547-553$

[16] ASSOCIAÇÃO BRASILEIRA DE NORMAS TÉCNICAS. Agregado para concreto - NBR 7211. Rio de Janeiro, 2009.

[17] BRITISH STANDARD. Testing hardened concrete: compressive strength of test specimens - NP EN 12390-3, 2009.

[18] VEDACIT®. Catálogo técnico Compounde $®$ adesivo. Disponível em: http://www.vedacit.com.br/neu/produtos. php?33. Acesso em: Março de 2018.

[19] ASSOCIAÇÃO BRASILEIRA DE NORMAS TÉCNICAS. Projeto de estruturas de concreto - Procedimento NBR 6118. Rio de Janeiro, 2014. 